the speed of glutaraldehyde at their respective minimum effective concentrations.

\section{REFERENCES}

1. Alvarado CJ, Stolz SM, Maki DG. Nosocomial infection and pseudoinfection from contaminated endoscopes and bronchoscopes. MMWR 1991;40:675-678 (including editorial note)

2. Nelson KE, Larson PA, Schraufnagel DE, Jackson J. Transmission of tuberculosis by flexible fiberbronchoscopes. Am Rev Respir Dis 1983;127:97-100.

3. Spach DH, Silverstein FE, Stamm WE. Transmission of infections by gastrointestinal endoscopy and bronchoscopy. Ann Intern Med 1993;118:117-128.

4. Wheeler PW, Lancaster D, Kaiser AB. Bronchopulmonary cross-colonization and infection related to mycobacterial contamination of suction valves of bronchoscopes. J Infect Dis 1989;159:954-958.

5. Ascenzi JM, Ezzell RJ, Wendt TM. A more accurate method for measurement of tuberculocidal activity of disinfectants. Appl Environ Microbiol 1987;53:2189-2192.

6. Isenberg HD, Giugliano ER, France K, Alperstein P. Evaluation of three disinfectants after in-use stress. J Hosp Infect 1988;11:278-285.

7. Robison RA, Osguthorpe RJ, Carroll SJ, Leavitt RW, Schaalje GB Ascenzi JM. Culture variability associated with the US Environmental Protection Agency Tuberculocidal Activity Test Method. Appl Environ Microbiol 1996;62:2681-2686.

8. Newman KA, Tenney JH, Oken HA, Moody MR, Wharton R, Schimpff SC. Persistent isolation of an unusual Pseudomonas species from a phenolic disinfectant system. Infect Control 1984;5:219-222.

9. Sautter RL, Mattman LH, Legaspe RC. Serratia marcescens meningitis associated with contaminated benzalkonium chloride solution. Infect Control 1984;5:223-225.

10. vanKlingeren $B$, Pullen W. Glutaraldehyde resistant mycobacteria from endoscope washers. J Hosp Infect 1993;25:147-149.

11. Russell AD, Hammond SA, Morgan JR. Bacterial resistance to antiseptics and disinfectants. J Hosp Infect 1986;7:213-225.

12. US Environmental Protection Agency. Tuberculocidal activity test method. In: Campt DD, ed. Data Call-In Notice for Tuberculocidal Effectiveness Data for All Antimicrobial Pesticides With Tuberculocidal Claims. Washington, DC: US Environmental Protection Agency; 1988:1-8.

13. Association of Official Analytical Chemists. Tuberculocidal activity of disinfectants. In: Williams S, ed. Official Methods of Analysis of the $A O A C$. 14th ed. Arlington, VA: AOAC; 1984:73-74.

14. Rutala WA, Cole EC, Wannamaker NS, Weber DJ. Inactivation of
Mycobacterium tuberculosis and Mycobacterium bovis by 14 hospital disinfectants. Am J Med 1991;91(suppl 3B):267S-270S.

15. Collins FM, Montalbine V. Mycobactericidal activity of glutaraldehyde solutions. J Clin Microbiol 1976;4:408-412.

16. Cole EC, Rutala WA, Nessen L, Wannamaker NS, Weber DJ. Effect of methodology, dilution, and exposure time on the tuberculocidal activity of glutaraldehyde-based disinfectants. Appl Environ Microbiol 1990;56:1813-1817.

17. Urayama S, Kozarek RA, Sumida S, Raltz S, Merriam L, Pethigal P. Mycobacteria and glutaraldehyde: is high-level disinfection of endoscopes possible? Gastrointest Endosc 1996;43:451-456.

18. Association of Official Analytical Chemists. Tuberculocidal activity of disinfectants. In: Official Methods of Analysis of the AOAC. 13th ed. Arlington, VA: AOAC; 1980:65-66.

19. Association Francaise de Normalisation (AFNOR). Recueil de normes francaises des antiseptiques et desinfectants. In: Antiseptics and Disinfectants. Edition bilingue. Paris, France: AFNOR; 1981.

20. Best M, Sattar SA, Springthorpe VS, Kennedy ME. Comparative mycobactericidal efficacy of chemical disinfectants in suspension and carrier tests. Appl Environ Microbiol 1988;54:2856-2858.

21. Best M, Sattar SA, Springthorpe VS, Kennedy ME. Efficacies of selected disinfectants against Mycobacterium tuberculosis. J Clin Microbiol 1990;28:2234-2239.

22. Sonntag HG. Desinfektions verfahren bei Tuberculose. Hygiene und Medizin 1978;3:322-325.

23. Sonntag HG, Hingst V. Comparative studies on the effects of disinfectants on $M$. tuberculosis and $M$. terrae. Zentrablatt Bakteriologie B: Hygiene 1985;181 (Serie B):31. Abstract.

24. vanKlingeren $B$, Pullen $W$. Comparative testing of disinfectants against Mycobacterium tuberculosis and Mycobacterium terrae in a quantitative suspension test. I Hosp Infect 1987;10:292-298.

25. Griffiths PA, Babb JR, Fraise AP. Mycobacterium terrae: a potential surrogate for Mycobacterium tuberculosis in a standard disinfectant test. $J$ Hosp Infect 1998;38:183-192.

26. Hingst V, Wurster C, Sonntag HG. A quantitative test method for the examination of antimycobacterial disinfection procedures. Zentrablati fur Hygiene und Umweltmedizin 1990;190:127-140.

27. Jette LP, Ringuette L, Ishak M, Miller M, Saint-Antoine P. Evaluation of three glutaraldehyde-based disinfectants used in endoscopy. $J$ Hosp Infect 1995;30:295-303.

28. Alfa MJ, Sitter DL. Inhospital evaluation of orthophthalaldehyde as a high level disinfectant for flexible endoscopes. J Hosp Infect 1994;26:15-26.

29. Robison RA, Robinson DF, Ploeger BJ, Christensen RP. Clinical and laboratory efficacy tests of a new disinfectant. J Dent Res 1991;70:438. Abstract.

\title{
PCR and Conventional Tests Used for MRSA Detection
}

\section{Gina Pugliese, RN, MS Martin S. Favero, PhD}

Conventional and molecular techniques are being used in the detection of methicillin resistance in Staphylococcus aureus (MRSA) but they do not always show concordant results. Araj and coinvestigators from the Department of Pathology and Laboratory Medicine, American University of Beirut Medical Center, Lebanon, compared a mecA polymerase chain reaction (PCR)-based amplification with the $1 \mu \mathrm{g}$ oxacillin disk-diffusion test and the Epsilometer test (E-test) for detection of minimum inhibitory concentrations (MICs). Among 31 isolates initially character- ized as MRSA by the disk-diffusion test, mecA was detected in only 13 isolates $(42 \%)$. The E-test showed a wide range of oxacillin MICs (0.5$>256 \mu \mathrm{g} / \mathrm{mL}$ ) among these 31 MRSA isolates: 7 isolates had an MIC of $>256 \mu \mathrm{g} / \mathrm{mL}, 1 \mathrm{had} 64 \mu \mathrm{g} / \mathrm{mL}, 2 \mathrm{had}$ $4 \mu \mathrm{g} / \mathrm{mL}, 2$ had $3 \mu \mathrm{g} / \mathrm{mL}, 1$ had 2.5 $\mu \mathrm{g} / \mathrm{mL}, 9$ had $2 \mu \mathrm{g} / \mathrm{mL}, 3$ had 1.5 $\mu \mathrm{g} / \mathrm{mL}, 5 \mathrm{had} 1 \mu \mathrm{g} / \mathrm{mL}$, and 1 had 0.5 $\mu \mathrm{g} / \mathrm{mL}$.

Comparing the mecA PCR results with the E-test oxacillin MIC findings revealed that mecA was detected in 7 of 8 isolates $(87.5 \%)$ with an MIC of $\geqslant 64 \mu \mathrm{g} / \mathrm{mL}$, in 3 of 14 isolates (21.4\%) with an MIC of 2 to $4 \mu \mathrm{g} / \mathrm{mL}$, and in 3 of 9 isolates (33.3\%) with an MIC of $<2$ $\mu \mathrm{g} / \mathrm{mL}$. B-Lactamase production was positive in 28 of 31 isolates $(90.3 \%$ ).
Because of this variation between tests, and because several resistance mechanisms are known to mediate methicillin resistance in $S$ aureus, the reliable detection of MRSA cannot be based solely on detection of mecA gene in $S$ aureus.

At this stage, and until new guidelines are introduced by an official body such as NCCLS, a combination of conventional methods alone or together with a molecular method should be used every time $S$ aureus is tested for detection of methicillin resistance.

FROM: Araj GF, Talhouk RS, Simaan CJ, Maasad MJ. Discrepancies between mecA PCR and conventional tests used for detection of methicillin resistant Staphylococcus aureus. Int J Antimicrob Agents 1999;11:47-52. 